certification processes is a way to further encourage other municipalities to eliminate MTCT in their territory.

\section{P3.03 PREVALENCE OF HIV/SYPHILIS AND QUALITY OF ANTENATAL CARE FOR PREVENTION OF MOTHER-TO- CHILD TRANSMISSION (PMTCT) IN PARTURIENT AND PUERPERAL WOMEN IN PARAGUAY}

Aguilar Gloria ${ }^{1,2}{ }^{1}{ }^{1}$ Kawabata Anibal, ${ }^{3}$ Miranda AE, 'Estigarribia Gladys. 'Samudio Tania. ${ }^{1}$ Recalde Hugo, 'Giménez Liliana, 'López GladdysRios-González Carlos Miguel, '. ${ }^{1}$ Universidad Nacional de Caaguazú, Coronel Oviedo, Paraguay; ${ }^{2}$ Universidade Federal do Espirito Santo (UFES), Vitoria, Brazil; ${ }^{3}$ National Program of HIVIAIDS,Asunción, Paraguay

\subsection{6/sextrans-2017-053264.240}

Introduction In recent years Syphilis has been a priority public health problem in Latin American and Caribbean countries (LAC), added to the problem of mother-to-child transmission (MTCT) of HIV. Our goal is to determine the prevalence of $\mathrm{HIV} /$ syphilis and measure the quality of antenatal care for prevention of MTCT in parturient and postpartum women attending public health facilities in Paraguay in 2013.

Methods Descriptive cross-sectional study using a standard survey and linked confidential serological tests. Data included public units at National level. A stratified two-stage cluster sampling was performed and data were expressed in measures of central tendency, dispersion and tables of proportions.

Results A total of 8.256 postpartum and parturient women were admitted to the study and $92.48 \%$ attending prenatal care. HIV prevalence in postpartum/parturient women was $0.50 \%$ (95\% CI $0.36-0.69$ ) and of Syphilis was $4.18 \%$ (CI $95 \% 3.75$ to 4.65 ). In $65.93 \%$ of them, the first prenatal visit was performed before 20 weeks of gestation. $72.04 \%$ performed 4 or more prenatal visits and $58.03 \%$ of pregnant women presented both, prenatal visit before 20 weeks and $\geq 4$ prenatal visits. In $85.59 \%$ and $83 \%$, the tests for HIV and syphilis diagnosis were performed during pregnancy. The diagnostic tests fo sexual partners were available in $12.50 \%$ and $24.40 \%$ for HIV and syphilis, respectively. The treatment of sexual partners of pregnant women with syphilis was $21.40 \%$.

Conclusion HIV prevalence was low; however the prevalence of syphilis was high in postpartum and in parturient women in Paraguay. The percentage of prenatal care before 20 weeks of gestation was low and the percentages of performing the tests on the sexual partners and the treatment of syphilis were very low. Improving the access to and quality of antenatal care services and implement effective strategies for the notification and treatment of sexual partners in health services the timely implementation of 1 st prenatal care and, in particular, to include strategies for testing sexual partners.

\section{P3.04 PREDICTORS OF MORTALITY IN CHILDREN UNDER 15 YEARS OLD WHO ACQUIRED HIV FROM MOTHER TO CHILD TRANSMISSION IN PARAGUAY}

\footnotetext{
${ }^{1,2,3} \mathrm{G}$ Aguilar, AE Miranda ${ }^{2},{ }^{3} \mathrm{~T}$ Samudio, ${ }^{1} \mathrm{~A}$ Kawabata, ${ }^{4} \mathrm{~S}$ Muñoz ${ }^{5} \mathrm{~F}$ Galeano. ${ }^{1}$ Universidad Nacional de Caaguazu, Coronel Oviedo, Paraguay; ${ }^{2}$ Universidade Federal do Espirito Santo (UFES), Vitoria, Brazil; ${ }^{3}$ National Program of HIV/AIDS,Asunción, Paraguay; ${ }^{4}$ Universidad de la Frontera-Facultad de Medicina, Paraguay; ${ }^{5}$ Temuco, Chile Instituto de Medicina Tropical, Asunción, Paraguay
}

Introduction Paraguay has made efforts to improve the response to HIV infection, and it is important to assess the impact of interventions in paediatrics. To estimate predictors of mortality in children who acquired HIV from mother to child transmission, between January 2000 and December 2014.

Methods A birth cohort study among persons living with HIV infection (PLWH), they were $<15$ years of age at enrollment. We abstracted data from clinic records, using a standardised form; obtained the data of death from clinic records and confirmations of deaths from deaths' certificates. We used survival analysis techniques to estimate the incidence of death.

Results A total of 302 subjects were included in the survey. $71.4 \%$ younger than six years of age, $51.0 \%$ female, $74.3 \%$ were from the metropolitan area. There were 52 deaths (17.2\% of participants), resulting in an overall mortality rate of 1.86 deaths $/ 100$ person-years [ $95 \%$ confidence interval (CI) 1.39, 2.44]. The Children with baseline HIV viral load >100000 copies/mL were four times more likely to die than children with baseline HIV viral load $\leq 100.000$ (HR, 4.47; 95\% CI: 1.79, 11.10). Regarding age-stratified staging of disease, those children with stage 3 were four times more likely to die compared with children on Stage (1 and 2) (HR: 4,19; 95\% CI: 1,50,11,70). Those children with haemoglobin level $\leq 9 \mathrm{~g} / \mathrm{dL}$ at baseline have four time more chance to die compared with haemoglobin level $\geq 9 \mathrm{~g} / \mathrm{dL}$ (HR: 3.90; 95\% CI1.61, 9.80).

Conclusion The mortality of children with HIV in Paraguay is low. High HIV viral load, late stage and moderate or severe anaemia at first diagnosis time are associated with mortality. Improving prenatal care and paediatric follow-up in an effort to diagnose vertically infected children as early as possible should be an integrated part of the healthcare provided to the child with AIDS, and it is very important an action that may increase survival in these children.

Support: University of California, San Francisco's International Traineeships in AIDS Prevention Studies (ITAPS), U.S. NIMH, R25MH064712

\section{P3.05 CONTRIBUTION TO THE PARENTS' KNOWLEDGE OF ABOUT HERPES INFECTIONS IN CHILDREN}

${ }^{1}$ AJ Giesteira, ${ }^{2}$ DC Ferreira, ${ }^{3} \mathrm{HLB}$ Reis, ${ }^{4}$ MRL Passos. ${ }^{1}$ Mestranda em Materno Infantil UFF, Brazil; ${ }^{2}$ Professor da UNESA e UVA, Brazil; ${ }^{3}$ Doutoranda - UFES, Brazil; ${ }^{4}$ Professor Titular e chefe do setor de DST - UFF, Brazil

\subsection{6/sextrans-2017-053264.242}

Introduction The Herpes Simplex Virus (HSV) is an infection caused by two types of viruses. The type-1 (HSV-1), which is more common in the oralabial region and the type 2 (HSV-2) in the genital region. The estimate is that $60 \%-80 \%$ of adults in the world have the type 1 virus, and the type- 2 prevalence is lower. $90 \%$ of individuals affected by the virus are asymptomatic.

Methods This is a sectional and quantitative study, where a public interview was used with those responsible for children, who were infected or not by herpes simplex. The total of 140 guardians were evaluated, being 121 women and 19 men, and through these data regarding their children was collected. The clinic scenario was women specialised care. The tests used in the statistics analysis were: chi-square and Fisher Exact test. 
Results The guardians described that 13 of them were infected (11 women and two men). Among the total number of interviewees, only 7 individuals stated that the form of transmission would be through oral contact and/or sexual violence, and $47.14 \%$ of the total reported not knowing how the HSV is transmitted. Among the children, the guardians reported that 6 had at least one episode of infection.

Conclusion The research showed that, in general, there is a lack of knowledge about the herpes infection. It is also evident, that the lack of knowledge can contribute in to diagnosis delay, in the possibility of household's transmission and hindering the prevention of infectious complications.

\section{P3.06 INITIAL EVALUATION OF VIRAL LOAD IN PEOPLE LIVING WITH HIV IN CAMAÇARI, ONE OF THE FOUR MOST POPULATED CITY IN BAHIA, BRAZIL}

A Farias, P Farias, R Penna, A Borges. Reference Centre in HIV/STI, Camaçari, Brazil

\subsection{6/sextrans-2017-053264.243}

Introduction: There are many different ways to control HIV epidemic today, instead of condom. In fact, because HIV treatment has demonstrated the most substantial effect on HIV incidence, it will be impossible to end the epidemic without bringing treatment to all patients living with the virus. Then, this study tries to analyse how the patients are well controlled in their HIV viral load in Camaçari, one of the most comercial and populated city in the state of Bahia, a northeast area in Brazil.

Methods Between November 2015 and November 2016, it was collected some data from about 236 of all 492 patients who have been cared to HIV at the only Centre of treatment in Camaçari, a service that has been assisted by a multidisciplinary team like Infectious Diseases assistance, Gynaecologist, Psychologist, Pharmaceutical, Nutritionist and Social Service.

Results $80,5 \%(190)$ of 236 patients had viral load in the blood less than 1000 copies $/ \mathrm{ml}$. These, 46,84\%(89) were men, $53,16 \%(101)$ were women. The average age was 39 years old and medium age was 40 . From the patients who were under control, 73,16\%(139) were taking two nucleoside inhibitors plus one non nucleoside inhibitor and from all, 64,74\%(123) were using Tenofovir, Lamivudine and Efavirenz as a single dosage per day, as Brazilian guideline recommended. 19,5\% (46) had more than 1000 copies/ml. 58,7\%(27) were men and $41,3 \%(19)$ were women. The average age was 40 years old and medium age was 37 . Patients who weren't under viral load control were divided in three different groups: genotype needed $(28,26 \%)$, problems with antirretroviral adherence $(34,78 \%)$ and necessities to start medication quickly (36,96\%). A multidisciplinary group was created to help patients in these conditions, especially for better adherence.

Conclusion It's really possible to get undetectable viral load in $90 \%$ from all patients by 2020 , maybe even more in certain circumstances, based on Brazilian public health care system and defining strategies to change detectable in suppressed viral load, like getting a multidisciplinary team with health care providers.
P3.07 SEXUAL PROFILE AND PSYCHOSOCIAL ASPECTS OF A GROUP OF HIV INFECTED WOMEN IN RIO DE JANEIRO

${ }^{1}$ AAS Helena, ${ }^{2}$ DC Ferreira, ${ }^{3}$ MRL Passos, ${ }^{4}$ AJ Giesteira*, ${ }^{5} \mathrm{HLB}$ Reis, ${ }^{6} \mathrm{~S}$ Muchele, ${ }^{6} \mathrm{R}$ Peres. ${ }^{1}$ Mestre em Materno Infantil - UFF, Brazil; ${ }^{2}$ Professor da UNESA e UVA, Brazil; ${ }^{3}$ Professor Titular e chefe do setor de DST - UFF, Brazil; ${ }^{4}$ Mestranda em Materno Infantil - UFF, Brazil; ${ }^{5}$ Doutoranda - UFES, Brazil; ${ }^{6}$ Farmacêutica - UNIIABEU, Brazil

\subsection{6/sextrans-2017-053264.244}

Introduction Women living with HIV have special features that arouse the interest of the scientific community, once they bring in themselves subjectivities that are beyond questions of clinical order. The objective of this study was to identify the patients' sexual and psychosocial profile of a public hospital in the state of Rio de Janeiro.

Methods A cross-sectional study and a semi structured interview with $70 \mathrm{HIV}$-infected women was carried out from April 2012 to March 2013. The patients were from an AIDS outpatient service of a hospital in Nova Iguaçu, in the State of Rio de Janeiro.

Results The average age of the participants was 34.9 years $(\mathrm{SD}= \pm 11.2)$. More than half of women 55 (78.6\%) acquired the infection through sexual intercourse. As for the marital status, 27 (38.6\%) were single and 29 (41.4\%) were married/ stable union. 68 (97.2\%) reported heterosexual orientation and $42(60 \%)$ reported having active sexual life. Half of these women had occupation/employment, and few had already left the job because of infection, they reported that companies they worked at had no knowledge about the disease. The most common reasons cited were prejudice and by considering a matter of personal agenda. As for the self-perception, 38 $(54.3 \%)$ of the evaluated women showed no satisfaction with their bodies, and 21 (30\%) experienced a possible reduction of libido after infection. The use of HAART occurred in 51 $(72.9 \%)$ patients, and even those classified as their biggest challenges in achieving treatment: adherence and access to the hospital, both with its implications.

Conclusion Our findings demonstrate the need to develop further health strategies in order to contribute to the comprehensive care that is being provided to these women, regarding their social reinsertion (occupation/employment), education, risk behaviour and preventive practices, serodiscordant relationships, disclosure, satisfaction with body and also the adherence to the proposed treatment.

\section{P3.08 STI PREVALENCE AND CORRELATES OF MORAL JUDGMENT AND BELIEF OF HIV TRANSMISSION THROUGH CASUAL CONTACT IN ADOLESCENTS ATTENDING PUBLIC HIGH SCHOOLS IN TWO DISTRICTS IN PANAMA}

${ }^{1} \mathrm{~A}$ Gabster, ${ }^{2} \mathrm{~GB}$ Arteaga, ${ }^{1} \mathrm{~A}$ Martinez, ${ }^{3} \mathrm{E}$ Mendoza, ${ }^{1} \mathrm{~J}$ Dyamond, ${ }^{1} \mathrm{O}$ Castillero, ${ }^{1} \mathrm{~J}$ Castillo, ${ }^{1} \mathrm{~A}$ López, ${ }^{1} \mathrm{~N}$ Mojica, ${ }^{1,2} \mathrm{JM}$ Pascale. 'Instituto Conmemorativo Gorgas de Estudios de la Salud, Panama, Panama; ${ }^{2}$ Facultad de Medicina, Universidad de Panamá, Panama, Panama; ${ }^{3}$ Facultad de Ciencias Naturales, Exactas y Tecnología, Universidad de Panamá, Panamá, Panamá

\subsection{6/sextrans-2017-053264.245}

Introduction Moral judgments (MJ) against people living with HIV (PLHIV), and belief of HIV transmission through casual contact (CC), lead in varying to degrees to social exclusion, discrimination, and violence. This study estimates the prevalence of HIV and other sexually transmitted infections (STI), 